\author{
JAROSŁAW WIAZOWSKI* \\ Warsaw (Poland) \\ ORCID ID: https://orcid.org/oooo-ooo1-6198-0370
}

\title{
DOES TACTILE IMAGE HAVE TO BE TACTUAL?
}

\begin{abstract}
This article is an analysis of educational assistive technologies that support learners with visual impairments in access to and interaction with graphics for mathematics and related academic areas. We will focus on options for students who require non-visual displays accessed via different remaining senses. Images, diagrams, tables or graphs constitute a significant portion of contemporary math textbooks students work with in schools (Dias et al., 2010; Edman, 1992). They convey information in a more succinct format or illustrate concepts that need a graphical presentation. Options available to put the students with visual impairments on a par with their sighted peers when it comes to creating and interacting with non-visual graphics will be listed and discussed. What has been thought of touch-only information delivery format, has been gaining a new interaction and exploration modality. We will propose a classification of non-visual graphics and how these different propositions impact the didactic process.
\end{abstract}

Keywords: tactile; image; blind; sonification; mathematics; audio; graph.

\section{Introduction}

This article is an analysis of educational assistive technologies that support learners with visual impairments, that is those who are blind or have low vision, in access to and interaction with graphics for mathematics. We will particularly focus on options for students who require non-visual displays accessed via different remaining senses. Images, diagrams, tables or graphs constitute a significant

* PhD Jarosław Wiazowski, Cardinal Stefan Wyszyński University in Warsaw, Poland, Faculty of Education; e-mail: dydaka2015@gmail.com. 
portion of the content contained in contemporary math textbooks students work with in schools (Dias et al., 2010; Edman, 1992). They convey information in a more succinct format or illustrate concepts that need a graphical presentation. Students with visual impairments who follow the general curriculum require appropriate adaptations to have equal access to both numerical and graphical information. Researchers claim that learners with limited vision struggle with non-numerical representations in math (Beck-Winchatz \& Riccobono, 2008; Smith \& Smothers, 2012). Today's technology abounds with propositions that facilitate preparation of accessible learning material for learners who are blind or have low vision. Students employ and combine different senses when engaged in mathematical tasks. Options available to put the students with visual impairments on a par with their sighted peers when it comes to creating and interacting with non-visual graphics will be listed and discussed. What has been thought of as touch-only information delivery format, has been gaining a new interaction and exploration modality. We will propose a classification of non-visual graphics and how these different propositions impact the didactic process.

\section{Non-visual formats}

The most common typology of assistive technology corresponds to the complexity of particular solutions (Wiazowski, 2015). We divide them into low, mid and high tech categories. The complexity relates to the physical structure of the system, number of functions and options, and the amount of training necessary to master the tool so that it can be functionally implemented in the classroom. Non-visual graphics is no different from this general categorization and we can label available options according to this typology. Having analyzed current propositions being present in educational settings or having a potential to become learning aids in a foreseeable future, the author proposes the following grouping of non-visual imagery (see Figure 1). Eye-free graphics are shelved on four levels starting with tactile, through two different combinations of touch and audio, ending with audio. The division reflects the primary media (techniques) students will apply to access and interact with non-text information.

Each of these categories have their own subsets with distinguishing characteristics. Tactile graphics is defined here as imagery that is accessed and explored by the sense of touch only. A learner using their hands and applying tactual exploration techniques attempts to understand the content of the image. In the tactile-audio subcategory the touch is the primary medium that receives support from the auditory feedback, while in the audio-tactile group, the touch is led by audio cues. This format is software-based because the graphical representations are digital. Hardware - a mobile device with a touch screen - is only a display tool. The audio feedback itself contains two subgroups: verbal audiodescription and non-verbal sound effects. Eventually the fourth category, audio, contains representations that 


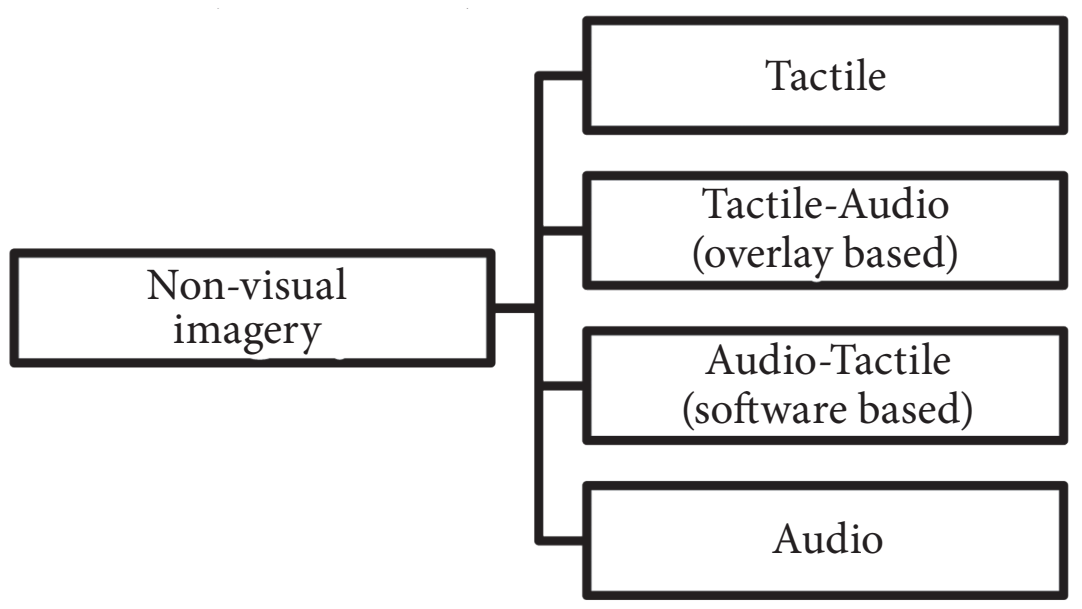

Figure 1. Non-visual imagery classification (own elaboration)

Source: own elaboration.

are realized only through the sense of hearing. Graphs and diagrams are generated digitally by graphing software and a learner accesses the renderings by listening to the peregrinating sound. More detailed discussion about this classification will be provided in the following sections of this article.

We have here two categories where both touch and hearing are involved in the process of interaction. To highlight which sense is primary and which secondary, we gave these groups separate names - tactile-audio and audio-tactile, with respectively touch and audio medium being the leading one. Some authors use these two terms interchangeably however we find it prudent to make this distinction because these categories require somewhat different touch exploration skills of the student. In the tactile-audio group learners are exposed to physical raised graphics, while in case of audio-tactile solutions their fingers are placed over a flat screen. When navigating a tactual printout the student would normally use both hands. As of now, most screen-based graphics software allows for one hand exploration.

Literature is replete with articles about tactile graphics in education. Majority of publications are technical in nature. Readers can find information about technologies used or improved to either produce or interact with non-visual illustrations. A fair number of titles compare and contrast engineering behind various inventions (Götzelmann, 2018; Moraru \& Boiangiu, 2015). Götzelmann (2018) lists several technologies for tactile image conversion and production. They include automatic bitmap image conversion to the tactile format, automatic production of tactual images from scalable vector graphics, or generating tactile images from $3 \mathrm{D}$ objects by rendering line drawings. Others provide mathematical explanations of proposed technologies. Conference proceedings announce possible concepts or breakthroughs in the production of tactile images or devices that are meant to support interaction with tactual impressions (Mech at al., 2014). Still 
some inventions are tested by adults out of any educational context (Amberg et al., 2011; Baker et al., 2014, Rowell \& Ungar, 2003). A relatively modest scope of reviewed publications present either research or best practice on the application and implementation of available options in the educational settings (Landau et al., 2004; Aldrich \& Sheppard, 2001. Articles on tactile graphics for mathematics are few in number, making the existing ones especially valuable (Zebehazy \& Wilton, 2014). Yet they do not feed all the needs of everyday practitioners in school settings.

Traditionally learners with visual impairments would rely primarily on their sense of touch when exploring physical objects. Although the finger's resolution is much less precise than the eye resolution, the touch has provided a great venue to understand non-visual characteristics of relevant objects. Eyes can provide enough visual information to the brain so that it processes even the smallest nuances in color or detail, though the whole process is more complex than this (Lagunas et al., 2017, Moraru \& Boiangiu, 2015). Fingers are not able to send nearly as much information to the brain. They require a minimum of $2 \mathrm{~mm}$ between two elements to be detected or identified. In either case, the brain is fed with data that it pieces together for a complete image. The visual image however is by far more detailed and precise. We can easier generalize and categorize objects seen with our eyes. We can assess the size, weight, position, color and even texture when we look at an object, new or experienced before. The touch, although somewhat more limited, is also a great conduit through which a person can identify the shape, texture, temperature, or weight. Unlike sight, touch requires direct contact with an object to collect information about it. Moraru and Boiangiu (2015) discuss an option of using remaining functional senses in a blind person to restore their vision to a certain degree. They claim that technology we know today is advanced enough to create a visual prosthesis but up till now, no sustainable method has been developed. They say that "substitution of the senses aims only to recover the functionality of the damaged sense with no direct stimulation of the retina or brain, so it cannot produce real visual experience (sensations)" (p. 411). It is hard to deduce any implications for education at this point in time but we can assume that the better compensatory skills a person with profound visual impairments develops, the better their chances for constructing sound images in their visual cortex.

Children, beginning in pre-school, should be receiving appropriate instruction to master their touch sensitivity to construct tactile images in their minds. Tactile discrimination apart from being crucial in exploring objects, is prerequisite in learning to read in Braille. Haptic skills have multiple functions in compensating for the vision loss. They foster general cognitive development and particular abilities, including literacy and numeracy. Without being exposed to varied samples of tactile images and practicing graphicacy skills, explained as the ability to understand and create graphics (Åberg-Bengtsson \& Ottosson, 2006, Aldrich \& Sheppard, 2000), students will have limited chances to explore and read graphs, maps or other pictures independently in the future. Numerous publications prove the importance of access 
to non-visual displays in the education of learners with visual impairments. The lack of exposure to information other than textual results in incomplete understanding of various mathematical concepts (Dias et al., 2010). Blind learners are confined to memorization of certain facts that are later recited back. They are deprived of opportunities to discover, build, or develop their imagination. Aldrich and Sheppard (2001) found out that children are eager to play with and "draw" their own creations. These findings call for introduction of all possible means to education so that the youngest learners can develop their graphicacy skills along with creativity. Similarly, Zebehazy and Wilton (2014) concluded based on their research that students find graphics in math useful and helpful.

With that knowledge various forms of tactile learning aids need to be introduced into education of children with visual impairments. Więckowska and others (2011) admit that a bicentennial experience experts in visual impairments have gained, has proved the validity and usefulness of tactile material in education. They see value in images constructed from different fabrics and textures, professional reliefs, or raised line productions. Regardless of technology used, tactile images have to follow specific guidelines to be discernible and comprehensible for a child (Jakubowski, 2009; Schuffelen, 2002; Yayla, 2009). Numerous resources, including the Braille Authority of North America, list and describe recommendations for creating methodologically correct tactile graphics (Mech et al., 2014; Prescher et al., 2014). Whoever attempts to create non-textual learning material needs to be familiarized with these recommendations. Tactual representations that deviate from established norms will cause a lot of damage and confusion. Learners will not receive complementary information from the images and will only waste their time for a useless tactile exploration (Więckowska, 2011). Zebehazy and Wilton (2014) are in accord with Aldridge and Sheppard (2001) that the usefulness of tactile graphics is strongly correlated with their quality. It is advised that teachers familiarize themselves with tools and materials they are planning to use prior to their implementation. A dry run will let them understand what is possible and what are potential limitations of these options. With this knowledge they can set appropriate tasks and expectations for their students.

\section{From low tech to highest tech}

Teachers, parents, and even students can create tactile graphics with a range of tools from low tech materials and tools to advanced technologies. The choice will depend on a variety of factors. Primarily it has to be determined what school tasks the student is expected to complete. Other factors are: (a) density (number and spread of elements) (Cryer, 2008), (b) precision (lines, angles, dimensions), (c) durability (for a single use, or multiple uses), (d) flexibility (fixed elements or elements that need to be transformed), (e) Braille labelling and legends (addition or not of labels in Braille) (Dias et al, 2010; Götzelmann, 2018), (f) timing (pre-planned vs on the spot 
graphs). We assume here that availability of existing technologies is not problematic and all parties can tap into the resources necessary to meet particular curricular needs. Otherwise, teachers or students would have to resort to available options but this would mean that either the tasks have to be modified or the student could not complete it in a fashion similar to their sighted peers.

\section{Simple low to mid tech tools for tactile images}

It may seem obvious that mathematical (or geometrical) graphical representations need to precisely reflect numerical calculations. For example, when a student creates a graph from a function that should follow correct coordinates. However, there are tasks when students need only to understand the shape of a graph (e.g. parabola), and its position on the cartesian plane is not as important or relevant. All these variables allow for a selection of the most effective and efficient technologies. Several low tech options like raising markers, wax flexi-sticks, or bendable metal wires (coated for safety) will suffice to form a desired graph. These are off-theshelf items that can be obtained in regular stores that carry respective goods. Students and teachers can use them for ad-hoc graphs or simple diagrams and two-dimensional shapes.

When an instant drawing needs to be done, students and teachers can use dedicated sets made up of a rubberized board, special plastic sheets, known as German film (Thinkable, nd.; Rowell \& Ungar, 2003; Wiazowski, 2013), and additional tools with visual and tactile markings. Assuming a general reproduction of a particular shape is needed, students themselves, equipped with a stylus or a drawing wheel will create an instant tactile impression. The addition of adapted rulers, protractors, triangles, or compasses equips students with a learning tool that gives them both flexibility and opportunity to create graphs, charts or diagrams. Teachers can expect that the drawings will reflect the exact shape, measurements and proportions.

Microcapsule paper (or swell paper) with a thermal fuser constitute another tactile image production set (Rowell \& Ungar, 2003). Black drawings are created either by printing out an image on a laser printer or by sketching them with special markers with carbon-based ink. Such visual graphs are run through a fuser to swell up the black lines in the drawing. Usually the thicker the line, the higher and more pronounced it becomes. This option is primarily used by teachers to print and emboss images for their students. They prepare graphs with software, whether it be one specifically dedicated to mathematical imagery, or standard spreadsheets with an insert graph option. After required modifications that may include color removal, text-to-Braille translation of labels, or detail removal, the image is printed and is ready for conversion to a tactile version. Rowell and Ungar (2003) found out that this technique is preferred by younger teachers who praised it for "their capacity to create quick graphic impressions." (p. 4). Not only is this 


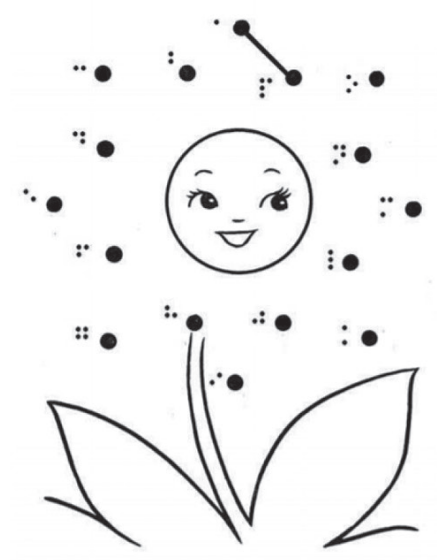

Figure 2: Connect the dots

Source: own elaboration.

form useful for teachers but it engages blind learners in assignments where graphs or diagrams should be designed. An example with a connect-the-dots described by Wiazowski (2013) illustrates how non-visual learners could submit their own non-textual math assignments.

Instead of a flower, a student would use the same technique (connecting tactual points) to plot a function or construct and name a shape that emerges after all points are connected. Having an option of running the same graph through the fuser several times, a student could first mark strategic points on the cartesian plane using a carbon-rich black marker, swell them up, and eventually draw a shape in a transformation exercise (reflection, rotation, translation or enlargement) that after being swelled up becomes tactual.

Low to mid tech math graphing solutions facilitate students in modifying and changing the non-numerical content. This is a critical feature. Learners are not only recipients of tactile information but become active creators. Blind students in particular with relatively limited exposure to tactile impressions will require ample opportunities to practice reading graphics and to attempt to recreate and create their own. Aldrich, Sheppard, and Hindle (2003) concluded in their research that despite a heavy load of images in state tests, learners with visual impairments are not receiving sufficient instruction in graphicacy. Functions, vectors, $2 \mathrm{D}$ and $3 \mathrm{D}$ impressions, geometrical representations, angles, are examples of mathematical concepts that are best illustrated in a non-text format. Because some are relatively complex, the use of different touch-friendly representations can foster their production and reception. Each student should find the most effective format for practicing graphicacy skills by imitating ready-made images and creating their own renderings. 


\section{High-end technology for tactile graphics with audio}

Some researchers argue that tactual imagery poses significant challenges due to high cognitive load that blind learners experience while exploring tactile graphics. Tactile illustrations can cause physical constraint because a child has to actively work with their hands to scan fragments of the image (Götzelmann, 2018). They are also more difficult to interpret by a non-visual user. It means that support from a sighted person may be called upon, limiting opportunities for the development of self-sufficiency and independence in the blind learner. This strain is supposed to be mitigated by combining tactile productions with additional auditory output. The auditory support comes in two flavors that can be provided independent of each other or that can complement each other. Verbal audio enhancement functions as a spoken label in addition to or as a replacement for tactile (Braille) labels. Where more convenient spoken labels improve exploration of mathematical images because they do not clatter the actual tactile overlay (Taibbi et al., 2014). Student's fingers trace only the essential elements of the image augmented by verbal labels, for example coordinates of a particular point on the cartesian plane. Audiodescription may also contain more elaborate explanations or support questions. This combination of touch and audio allows students to keep their fingers on the image at all times, rather than having to switch between the graphics and descriptions/questions pertaining to this particular image.

\section{Sonification in tactile-audio solutions}

This is an interesting group with a number of promising inventions that might increase access to mathematical images and foster understanding of math concepts among blind learners. To obtain a learning tool with which a student can independently explore new tactile images enhanced by auditory labels or descriptions, apart from the tactile overlays, additional peripheral devices are needed. Education has a growing selection of options at their disposal, from talking touch tablets, touch sensitive boards to smartphones or tablets with dedicated software and applications. At the time of writing two touchboard devices are available for education. In principle their most basic functionality is the same (Landau \& Gourgey, 2001, Gardner \& Bulatov, 2008). A tactile overlay is placed over a touch sensitive board connected to the computer running a corresponding software. Prior to the use in class, the teacher or their aids design an image that will need to be embossed or created otherwise with a condition that the surface is thin enough to be depressed under fingers of the student. The image when being designed in the authoring software is assigned selected areas with attached audio cues in a form of textual descriptions or sounds imitating natural phenomena or man-made devices, e.g. rain, car engines, etc. Math images will be enhanced by a narrator explaining various concepts illustrated by the graph or support questions 
that will lead a student to finding the correct answer. Some of these systems are packaged with interactive math curricular materials (Gardner et al, 2009). Where talking boards (or tablets) are not available teachers can propose students tactual $2 \mathrm{D}$ images augmented by $\mathrm{QR}$ code scanning applications on their mobile devices. Baker et al. (2016) used manually attached visual markers (QR-Codes) encoding text in tactile graphics to assign verbal explanations to dedicated data visualizations. This option has two fundamental requirements. The school needs to offer and/or allow access to wireless internet and blind students should be trained to locate and scan the markers. Some QR scanner applications have built-in systems guiding the blind user's smartphone to align it with the QR code for scanning.

Gay, Rivière, and Pissaloux (2018) showed their interest in haptic devices that do not require any embossed or raised overlays but can form tactile impressions with raising solenoid pins or bearing balls placed within the board itself. An image displayed visually on a computer screen is converted by appropriate software and sent to the matrix where selected pins/balls, known as taxels (tactile elements), are raised to form a tactile representation. This type of learning aid can be equated to digital visual images sighted students can work with. When the function changes, the tactile image also changes dynamically. According to the authors the refresh time might be of concern. It will differ from device to device but it is usually not longer than a few seconds (Gay et al, 2018). When we compare the time required to create even the simplest hard copy non-visual graph, the image update time seems inessential.

Haptic and audio-haptic solutions offer students yet another experience. Not only can they touch the graph but they can also manipulate it. A Phantom arm guides the student's hand when a curve is being explored (Ramloll et al., 2000; Sjostrom et al., 2003).

\section{Audio-tactile software based visualisations}

Some math graphs or diagrams may not always be very complex, therefore they are relatively easy to produce on the spot. But some non-visual images will be laborintensive and in such cases it might be more reasonable to resort to touch-screen applications where dynamically rendered graphs are accessed in a unique and heretofore infrequently experienced manner. Non-verbal sonification implemented in math imagery has mainly served as an audio interpretation of a plotted graph. Students would listen to the sounds traveling from one side to the other (panning) with a changing pitch (Bornschein et al., 2014). "Sonification enables blind students to understand the trend of the graph and relevant points such as maxima, minima and intersections" (Taibbi et al., 2014, p. 539). But the auditory feedback functions also as a navigation guide. With publications moving to the digital and online world, accessibility of Web-based scientific notation and representation has become particularly challenging (Sorge et al., 2019). Teams made up of software engineers 
and mathematicians propose solutions that blind users experience by tracing sonified visualisations. Unlike embossed graphs, with a few exceptions described above, software graphs can be easily edited and adjusted to reflect the changes in corresponding functions.

\section{Sonified (audio only) graphs}

It is often mistakenly assumed that learners who are blind possess exquisite tactile discrimination skills to access information written in Braille or presented in a touch-friendly format. It is yet another myth, besides the one that most, if not all, blind people are opera singers and have absolute hearing. Both of these senses do function as compensatory media and with practice may become more acute than in sighted people, but they are not given at birth, and should never be taken for granted. Adventitiously blind persons will struggle with developing and improving their tactual skills, especially if they lose their sight as adults. Depending on what they had been doing before the vision loss, they may never sharpen their touch sensitivity enough to use their fingertips for reading texts and interacting with tactile images. This could be one of the reasons why tactile representation may be off-limits to these individuals. Practicality and availability could be yet another factor that determines a possible omission of tactile impressions.

Brzostek and Mikułowski (2012) inform that software-based solutions that let students interpret non-speech sounds of different pitch corresponding to specific coordinates on the planes are one of the most economic and sought-after propositions for education. Audio-only formats as the very term suggests rely solely on the sonified representation of the graph or shape. The changes in the pitch and the panning of the sound draw an acoustic image. Mikułowski and Mańkowski (2008) add volume as the third parameter helpful in understanding the sound graph. They claim that this format "makes an easy way to explain two-dimensional diagrams for the blind student. It can be also extended to present $3 \mathrm{D}$ graphics by changing another sound parameters such as volume or tone, or to use so-called binaural sounds and the holophony phenomena" (p. 24). The student imagines and creates its mental representation by listening to the traveling sound.

Audio-only format appears to be retreating, making room for multimodal digital outputs. With that being said, the current events prove sonified presentations may not be totally phased out and students are likely to come across data expressed by non-speech feedback. Dynamic and automatic graphs showing the changing numbers of people and countries affected by COVID-19 were made available to people through an online project (Fusco, 2020). This form of eyes-free and handsfree exploration has not been researched extensively making it hard to verify its effectiveness. Nonetheless, it would indicate that non-visual learners need to be at a minimum made aware of such formats and be given opportunities to comprehend 
acoustically presented data because they will be exposed to sonographs in their after-school life.

\section{Conclusion}

While technology does not have all the answers, we can safely assume that nonvisual learners have a wide range of options in accessing and interacting with graphical information in mathematical education. Further targeted research on efficacy and usability of digital propositions cannot be avoided. Only thorough studies will qualify or disqualify non-traditional access to tactile graphics in education. The author comes across people with their predetermined convictions on the superiority of what they have been working with. Predominantly educators believe that solution $\mathrm{A}$ is better than solution $\mathrm{B}$, rather than determine when solution A can be better than solution B, and vice versa. Since new educational solutions are very likely to become more commonly available, students will expect them in their classes along with sufficient methodical instruction. For it to happen several conditions have to be met, including proper teacher training and technical support. Rubin et al (2015) investigated the quantity and quality of automation of mathematical education to students with visual impairments. They concluded that Polish schools lack digital tools blind students could use independently to study math. Similar sentiment resonates in the report by Fitzpatrick et al (2018) where surveyed teachers expressed bigger interest in sketching "a rough outline of a graph using a rubber mat and plastic foil, than to use complex hardware and software to achieve more or less the same result" (p. 25). Hopefully efforts like the one by Suzuki et al (2015) will revert the teacher's attitude and approach to higher end educational technologies that evidently can lead to an increase in access to and comprehension of graphics and visual concepts in mathematics and other STEM areas.

It is prudent to remember that students should develop various prerequisite skills to benefit from accessible non-visual displays. Więckowska (2011) informs that blind learners should understand basic shapes, spatial concepts and spatial relationships between objects. Because mathematical non-numerical concepts in their non-visual format should retain their specifications, students need to know how to use measurement instruments. The more frequent exposure to available and accessible graphical data students have, the better chances they will have to grasp mathematical concepts that are difficult to explain in a textual format.

Accessible graphics in math education is more than the ability to complete school tasks. Blind learners are given a chance to experience genuine educational and social inclusion. Ingenuity that engineers apply in their research and tests are very likely to propose new and improved forms of tactual and auditory engagement that all students will use in an inclusive setting. 


\section{References}

Åberg-Bengtsson, L., \& Ottosson, T. (2006). What lies behind graphicacy? Relating students' results on a test of graphically represented quantitative information to formal academic achievement. Journal of Research in Science Teaching, 43, 43-62. doi: 10.1002/tea.20087.

Aldrich, F.K., \& Sheppard, L. (2000). Graphicacy: The fourth “r”. Primary Science Review, 64, 8-11.

Aldrich, F.K., \& Sheppard, L. (2001). Tactile graphics in school education: perspectives from pupils. British Journal of Visual Impairment, 19(2), 69-73. https://doi. org/10.1177/026461960101900204.

Aldrich, F.K., Sheppard, L., \& Hindle, Y. (2003). First steps towards a model of tactile graphicacy. The Cartographic Journal, 40, 283-287. doi: 10.1179/000870403225013014.

Baker C.M., Milne, R.L., Drapeau, R., Scofield, J., Cynthia L., Bennett, L.C., \& Ladner, E.R. (2016). Tactile graphics with a voice. ACM Trans. Access. Comput. $8(1), 1-22$.

Beck-Winchatz, B., \& Riccobono, M. (2008). Advancing participation of blind students in science, technology, engineering, and math. Advances in Space Research, 42, 1855-1858. doi: 10.1016/j.asr.2007.05.080.

Baker, C.M., Milne, L.R., Scofield, J., Bennett, C.L., \& Ladner, E.R. (2014). Tactile graphics with a voice: using $\mathrm{QR}$ codes to access text in tactile graphics. In Proceedings of the 16th international ACM SIGACCESS conference on Computers \& accessibility (ASSETS '14). Association for Computing Machinery, New York, NY, USA, 75-82. DOI:https://doi.org/10.1145/2661334.2661366.

Bornschein, J., Prescher, D., \& Weber, G. (2014). SVGPlott - Generating Adaptive and Accessible Audio-Tactile Function Graphs. In K. Miesenberger et al. (Eds.): ICCHP 2014, Part I, LNCS 8547, 588-595.

Brzostek-Pawłowska, J., \& Mikułowski, D. (2012). Techniki multimodalne zwiększające dostępność grafiki na stronach WWW i w elektronicznych dokumentach. Elektronika: konstrukcje, technologie, zastosowania, (53)11, 77-84.

Dias M.B., Rahman M.K., Sanghvi S, \& Toyama K. (2010). Experiences with lower-cost access to tactile graphics in India. In Proceedings of the First ACM Symposium on Computing for Development (ACM DEV '10). Association for Computing Machinery, New York, NY, USA, Article 10, 1-9. DOI:https://doi. org/10.1145/1926180.1926193.

Edman, P.K. (1992). Tactile Graphics. New York: American Foundation for the Blind. Fitzpatrick, D., Murray S., van Leendert A., Brzostek-Pawłowska J., \& Rubin, M. (2018). Analysis of ICT Tools and the Mathematical Education of Blind and Visually Impaired people in Ireland, Poland, the Netherlands, and Neighbouring Countries. Retrieved May 8, 2020, from: https:/project.euromath.eu/wp-content/ uploads/2018/10/O1_Report_EN.pdf. 
Fusco, G. (2020). A11Y Accessible Pandemic Data Bulletin. Retrieved May 30, 2020, from covid.ski.org on.

Gardner, J.A., Gardner, C.K., Jones, B., Hagen, K., Callaway, T., \& Jones, E. (2009). Viewplus Math And Science Curricula With Fully Accessible Illustrations. Conference presentation at CSUN International Conference on Technology and Disabilities, Los Angeles, CA.

Gardner, J.A., \& Bulatov, V. (2008, March). Making Scientific Graphics Accessible With Viewplus Iveo ${ }^{\oplus}$. In Proceedings of The 23 rd Annual International Technology \& Persons with Disabilities Conference. Los Angeles, CA: CSUN.

Gay, S., Rivière M.A., \& Pissaloux, E. (2018). Towards Haptic Surface Devices with Force Feedback for Visually Impaired People. In K. Miesenberger, G. Kouroupetroglou (Eds.), Computers Helping People with Special Needs. ICCHP 2018. Lecture Notes in Computer Science, vol 10897. Springer, Cham.

Goncu, C., \& Marriott, K. (2015). GraCALC: An Accessible Graphing Calculator. In Proceedings of the 17th International ACM SIGACCESS Conference on Computers \& Accessibility (ASSETS '15). Association for Computing Machinery, New York, NY, USA, 311-312. DOI:https://doi.org/10.1145/2700648.2811353.

Götzelmann, T. (2018). Visually Augmented Audio-Tactile Graphics for Visually Impaired People, Nuremberg: Nuremberg Institute of Technology.

Cryer, H. (2008). Exploring tactile graphics - which strategies work? RNIB Centre for Accessible Information (CAI) FINAL report, RNIB 24 November.

Jakubowski, M. (2009). Tyflografika - historia i współczesność, metody i technologie. Tyfloświat, 1, 36-40.

Lagunas, A., Domínguez, O., Martinez-Conde, S., Macknik S.L., \& Del-Río, C. (2017). Human eye visual hyperacuity: Controlled diffraction for image resolution improvement. Journal of Applied Physics. 122, 094501 https://doi. org/10.1063/1.4987017.

Landau, S., \& Gourgey, K. (2001). Development of a talking tactile tablet. Information, Technology and Disabilities, $7(2)$.

Landau, S., Holborow, R. \& Jane, E. (2004). The Use of the Talking Tactile Tablet for Delivery of Standardized Tests. In Proceedings of The Annual International Technology \& Persons with Disabilities Conference. Los Angeles, CA: CSUN.

Mech, M., Kwatra, K., Das, S., Chanana, P., Paul, R., \& Balakrishnan, M. (2014). Edutactile - A Tool for Rapid Generation of Accurate Guideline-Compliant Tactile Graphics for Science and Mathematics. In K. Miesenberger, D. Fels, D. Archambault, P. Peňáz, W. Zagler (Eds.), Computers Helping People with Special Needs. ICCHP 2014. Lecture Notes in Computer Science, vol 8548. Springer, Cham.

Michel, A., Frédéric, G., Lemaire-Semail, B., Olivo, P., Casiez, G., \& Roussel, N. (2011). STIMTAC: A tactile input device with programmable friction. Proceedings of the 24th Annual ACM Symposium on User Interface Software and Technology, Santa Barbara, CA, USA, October 16-19, 2011.7-8. 
Mikułowski, D., \& Mańkowski, J. (2008). An approach of explaining math function graphs through the sound representation for blind students. Studia Informatica: Systems and Information Technology, 1-2(22), 21-29.

Moraru, D., \& Boiangiu, C.-A. (2015). Seeing without Eyes: Visual Sensory Substitution. Journal of Information Systems \& Operations Management, 9(2), 1.

Pather, A.B. (2014). The Innovative Use of Vector-based Tactile Graphics Design Software to Automate the Production of Raised-line Tactile Graphics in Accordance with BANA's Newly Adopted Guidelines and Standards for Tactile Graphics, 2010. Journal of Blindness Innovation \& Research, 4(1), 1.

Prescher, D., Bornschein, J., \& Weber, G. (2014) Production of Accessible Tactile Graphics. In K. Miesenberger, D. Fels, D. Archambault, P. Peňáz, W. Zagler (Eds.), Computers Helping People with Special Needs. ICCHP 2014. Lecture Notes in Computer Science, vol 8548. Springer, Cham.

Ramloll, R., Yu, W., Brewster, S., Riedel, B., Burton, M., \& Dimigen, G. (2000). Constructing sonified haptic line graphs for the blind student: First steps. In: Proceedings of the 4 th International Conference on Assistive Technologies. ACM.

Rubin, M., Faderewski, M., \& Mikułowski, D. (2015). Badania stanu i potrzeb informatyzacji edukacji matematycznej uczniów niewidomych i słabowidzących w Polsce, e-mentor, 1(58), 34-40.

Rowell, J. \& Ungar, S. (2003) Feeling your way- a tactile map user survey. In Proceedings of the 21st International Cartographic Conference, Durban, South Africa, 10-16 August 2003.

Schuffelen, M (2002). On Editing Graphics For The Blind. A manual with examples, and for the interested layman a pictorial overview. Retrieved May 4, 2020, from http://www.heardutchhere.net/grbl/grblo.html.

Sorge, V., Ahmetovic, D., Bernareggi, C., \& Gardner, J. (2019) Scientific Documents. In Y. Yesilada, S. Harper (Eds.), Web Accessibility. Human-Computer Interaction Series. London: Springer.

Smith, D.W., \& Smothers, S.M. (2012). The role and characteristics of tactile graphics in secondary mathematics and science textbooks in braille. Journal of Visual Impairment \& Blindness, 106, 543-554.

Sjostrom, C., Danielsson, H., Magnusson, C., \& Rassmus-Grohn, K. (2003). Phantom-based haptic line graphics for blind persons. Visual Impairment Research, 5(1), 13.

Suzuki, M., Terada, Y., Kanahori, T., \& Yamaguchi, K. (2015). New Tools to Convert PDF Math Contents into Accessible e-Books Efficiently. Studies in health technology and informatics, 217, 1060-1064.

Thinkable. Retrieved from https://thinkable.nl/tactileview-a-wealth-of-tactile-images-for-a-visual-impaired-person/ on March 15, 2020

Taibbi, M., Bernareggi, C., Gerino, A., Ahmetovic, D., \& Mascetti, S. (2014). AudioFunctions: Eyes-Free Exploration of Mathematical Functions on Tablets. Computers Helping People with Special Needs: Part I, 537. 
Więckowska, E. (2011). Instrukcja tworzenia i adaptowania ilustracji i materiałów tyflograficznych dla uczniów niewidomych. Retrieved April 21, 2020, from http://pzn.org.pl/wp-content/uploads/2016/o7/instrukcja_tworzenia_i_adaptowania_ilustracji_i_materialow_tyflograficznych_dla_niewidomych.pdf.

Wiazowski, J. (2013). Creating tactile images - decision making process. In Proceedings of the 7 th International Convention on Rehabilitation Engineering and Assistive Technology (i-CREATe '13). Singapore Therapeutic, Assistive \& Rehabilitative Technologies (START) Centre, Midview City, SGP, Article 58, 1-4.

Wiazowski, J. (2015). Proces efektywnego doboru technologii wspierających edukację osób niewidomych i słabowidzących. In: K. Czerwińska, M. Paplińska, M. Walkiewicz-Krutak (Eds.), Tyflopedagogika wobec współczesnej przestrzeni edukacyjno-rehabilitacyjnej (15-178). Warszawa: APS.

Yayla, L. (2009). Huseby Zoom maps: A design methodology for tactile graphics. Journal of Visual Impairment \& Blindness, 103(5), 270-276.

Zebehazy, K.T., \& Wilton, A.P. (2014). Straight from the source: Perceptions of students with visual impairments about graphic use. Journal of Visual Impairment \& Blindness, 108(4), 275-286.

\section{CZY GRAFIKA DOTYKOWA MUSI BYĆ DOTYKOWA?}

Streszczenie: $\mathrm{W}$ artykule przeanalizowano edukacyjne technologie wspomagające uczniów z niepełnosprawnością wzroku w dostępie do grafik matematycznych i z pokrewnych dziedzin nauk ścisłych. Autor skoncentrował się na opcjach grafik przeznaczonych dla uczniów, które nie wymagają wersji dostępnych za pomocą innych zmysłów. Obrazy, diagramy, tabele i wykresy stanowią znaczną część współczesnych podręczników matematycznych, z którymi uczniowie pracują w szkołach (Dias i in., 2010; Edman, 1992). Dostarczają one koniecznych informacji w zwięzłym formacie i ilustrują pojęcia wymagające wyjaśnienia. Dostępne opcje pozwalają uczniom z niepełnosprawnością wzroku osiągnięcie podobnych możliwości co ich widzący rówieśnicy. Dzięki temu dane, tradycyjnie dostępne tylko przez dotyk, zyskały nową modalność interakcji i eksploracji.

Słowa kluczowe: dotykowy; obraz; niewidomy; sonifikacja; matematyka; audio; wykres. 